- FINANSE I PRA WO FINANSO WE.

- Journal of Finance and Financial Law

Marzec/March 2021 • vol. 1(29): 95-107

\title{
KRYTERIA DECYZYJNE KONSUMENTA NA RYNKU UBEZPIECZEŃ MAJĄTKOWYCH
}

https://doi.org/10.18778/2391-6478.1.29.06

\section{Magdalena Lubaś*}

\section{CLIENT DECISION-MAKING CRITERIA ON THE PROPERTY INSURANCE MARKET}

\begin{abstract}
Consumers wanting to guard against losses resulting from unforeseen random events, decide to buy insurance. It is recognized that their decisions are often irrational. The aim of the study was to determine the importance attributed by consumers to the most important criteria when choosing insurance. The study was conducted by means of a diagnostic survey using the CAWI technique in January 2020 on a group of 150 people. The results showed that the most important factors which consumers are guided by when choosing their insurance are: price, attractiveness of the offer and terms of the contract.
\end{abstract}

Keywords: property insurance, consumer behavior, risk.

JEL Class: G22, G32, D8, D91.

\footnotetext{
* Lic., Wydział Zarządzania i Komunikacji Społecznej, Uniwersytet Jagielloński w Krakowie; https://orcid.org/0000-00030572-6145.
} 


\section{WSTĘP}

Obecnie na rynku działa wiele podmiotów świadczących usługi z zakresu ubezpieczeń i reasekuracji, co skutkuje występowaniem silnej konkurencji o klienta. Rywalizujące podmioty muszą więc stale reagować na zmieniające się otoczenie, w tym ewolucję wymagań i potrzeb klientów. Mimo to, badania nad zachowaniami konsumentów należą do najmłodszych i zarazem szybko się rozwijających. Pojawia się wiele publikacji odnoszących się do zachowań na rynku dóbr i usług konsumpcyjnych. Niewiele jest jednak badań poruszających zachowanie konsumentów na rynku ubezpieczeniowym, w wyniku czego obszar ten nie jest w pełni rozpoznany.

Celem niniejszej pracy jest określenie znaczenia przypisywanego przez konsumentów najważniejszym kryteriom decydującym o wyborze ubezpieczenia. Badanie zostało wykonano metodą sondażu diagnostycznego $\mathrm{z}$ wykorzystaniem techniki CAWI na próbie 150 osób. Kwestionariusz składał się z 28 pytań zamkniętych, w których pytano jaką wagę poszczególnym cechom oferty ubezpieczeniowej przypisują konsumenci. Cechy te pochodzą z przeglądu wcześniejszych badań na temat zachowań konsumentów rynku ubezpieczeniowym, a ich zbiorcze zestawienie pozwala dokonać analizy porównawczej, które cechy są dla ubezpieczających się najważniejsze.

Artykuł ten wpisuje się nurt badawczy analizy klienta na rynku ubezpieczeniowym, uzupełniając dotychczasowy stan wiedzy w tym obszarze. Jednocześnie, wyniki przeprowadzonych badań mogą stanowić praktyczną wskazówkę dla przedsiębiorstw świadczących usługi z zakresu ubezpieczeń, w kwestii dostosowywania oferty do potrzeb potencjalnych klientów.

\section{PRZEGLĄD LITERATURY}

\section{Podstawy funkcjonowania rynku ubezpieczeń}

Ze względu na łączenie się w dziedzinie ubezpieczeń aspektów z pogranicza ekonomii, prawa, finansów oraz marketingu, problematyka ta ma charakter interdyscyplinarny. $\mathrm{Z}$ tego też względu, w literaturze przedmiotu występuje mnogość definicji odnoszącej się do ubezpieczeń. Greene definiuje ubezpieczenie jako instytucję ekonomiczną, redukującą ryzyko przez podanie wspólnemu zarządowi grupy przedmiotów, rozłożonych w taki sposób, że suma przypadkowych zagrażających im szkód jest możliwa do określenia w wąskich granicach (Grenne i Trieschman, 1981: 21). Vaughan (1997: 34) uznał natomiast, że ubezpieczenie w podstawowym ujęciu stanowi transfer ryzyka $\mathrm{z}$ jednostki na grupę, a także podział ciężaru strat/potrzeb finansowych na członków grupy. Nie trudno więc uznać, że rynek usług ubezpieczeniowych odgrywa kluczową 
rolę w funkcjonowaniu całej gospodarki oraz podmiotów sfery realnej. $\mathrm{Z}$ punktu widzenia klienta, ubezpieczenie należy rozumieć jako usługę niematerialną, polegającą na odpłatnym przeniesieniu na zakład ubezpiec zeń tzw. ryzyka czystego (Ronka-Chmielowiec, 2002: 80). Ryzyko czyste oznacza, że w przypadku zrealizowania się go powstaje strata, zaś niezrealizowanie nie powoduje zysku.

Ubezpieczyciele dywersyfikują ryzyko, a następnie sprzedają je w zamian za składkę adekwatną do ryzyka (Samuelson i Nordhaus, 2012: 218). Zdaniem Warkało, ubezpieczenie to forma repartycji strat $\mathrm{w}$ dwóch wymiarach:

- przestrzennej, gdyż fundusz, z którego pokrywana jest strata, tworzony jest ze składek wielu osób;

- czasowej, gdyż składki te są płacone z reguły przez długi okres, często w ratach (Warkadło, 1969: 418).

Z ekonomicznego punktu widzenia, rynek ubezpieczeń można analizować z perspektywy mikro oraz makro. $\mathrm{W}$ ujęciu mikorekonomicznym, rynek ten rozpatrywany jest z punktu widzenia zakładów ubezpieczeń. Głównymi podmiotami wstępującymi na tym rynku są aktualni oraz przyszli klienci. W perspektywie makroekonomicznej, ubezpieczenia rozpatruje się jako ogół stosunków wymiany zachodzącymi pomiędzy uczestnikami tego rynku, czyli stroną podmiotową złożoną $\mathrm{z}$ ubezpieczających transferujących ryzyko związane $\mathrm{z}$ ochroną dóbr osobowych i majątkowych w zamian za ustaloną składkę i przedmiotową składającą się z jednej strony z potrzeby ochrony posiadanych dóbr, zaś z drugiej z zakładów ubezpieczeniowych wyspecjalizowanych $\mathrm{w}$ przejmowaniu tego rodzaju ryzyka (Płonka, 2013: 25).

Zgodnie z ustawą z dnia 11 września 2015 roku o działalności ubezpieczeniowej i reasekuracyjnej (Dz.U. 2015, poz. 1844), zakład ubezpieczeń może prowadzić w Polsce działalność ubezpieczeniową wyłącznie w formie spółki akcyjnej, towarzystwa ubezpieczeń wzajemnych lub głównego oddziału - oddziału zakładu ubezpieczeń z państwa niebędącego członkiem Unii Europejskiej.

Produkt ubezpieczeniowy charakteryzuje się swoim niematerialnym charakterem. Nie jest bowiem możliwe dokonanie wyceny za pomocą wrażeń zmysłowych, nie jest też możliwe magazynowanie go (Ronka-Chmielowiec, 2002). W przypadku rynku ubezpieczeń nie występuje rynek wtórny. Produkt ubezpieczeniowy posiada wartość użytkową oraz wymienną. Pierwsza z nich posiada zdolność do zaspokojenia określonej potrzeby (poczucia spokoju, pewności i bezpieczeństwa finansowego), druga zaś wskazuje na określoną cenę produktu (Ronka-Chmielowiec, 2002).

Istotnym z punktu widzenia zakresu badania jest dokonanie podmiotowego podziału ubezpieczeń na ubezpieczenia osobowe (związane z ryzykiem osobowym) oraz ubezpieczenia majątkowe (związane z ryzykiem majątkowym). Zgodnie $\mathrm{z}$ podziałem ryzyka zawartym $\mathrm{w}$ załączniku do ustawy o działalności 
ubezpieczeniowej, ubezpieczenia majątkowe przynależą do II działu ubezpieczeń. Tabela 1 prezentuje różnice pomiędzy ubezpieczeniami osobowymi a ubezpieczeniami majątkowymi.

Tabela 1. Porównanie ubezpieczeń osobowych i majątkowych

\begin{tabular}{|c|c|}
\hline Ubezpieczenie osobowe & Ubezpieczenie majątkowe \\
\hline \multicolumn{2}{|c|}{ PRZEDMIOT } \\
\hline $\begin{array}{c}\text { Ryzyko osobowe }- \text { m.in. związane z życiem, } \\
\text { zdrowiem czy zdolnością do wykonywania } \\
\text { pracy }\end{array}$ & $\begin{array}{l}\text { Przedmiotem jest mienie lub } \\
\text { odpowiedzialność cywilna }\end{array}$ \\
\hline \multicolumn{2}{|c|}{ PODMIOT } \\
\hline Wyłącznie osoby fizyczne & Osoby fizyczne i osoby prawne \\
\hline \multicolumn{2}{|c|}{ CZAS TRWANIA } \\
\hline $\begin{array}{l}\text { Umowa ubezpieczeniowa zostaje zawarta na } \\
\text { okres powyżej roku }\end{array}$ & $\begin{array}{c}\text { Umowa ubezpieczeniowa zostaje zawarta na } \\
\text { okres nie przekraczający jednego roku }\end{array}$ \\
\hline \multicolumn{2}{|c|}{ CHARAKTER SZKODY } \\
\hline $\begin{array}{l}\text { Szkoda ma charakter niewierny w pieniądzu } \\
\text { i nie zawsze jest to charakter negatywny }\end{array}$ & $\begin{array}{c}\text { Szkoda ma charakter wierny i w pieniądzu, } \\
\text { dotyczy zdarzenia negatywnego }\end{array}$ \\
\hline \multicolumn{2}{|c|}{ CHARAKTER UBEZPIECZENIA } \\
\hline Świadczenie & Odszkodowanie \\
\hline
\end{tabular}

Źródło: opracowanie własne na podstawie Kwiecień, 2016: 319-320.

Produkty ubezpieczeń majątkowych są dedykowane odbiorcom indywidualnym oraz korporacyjnym. W skład oferty tego typu ubezpieczeń wchodzą (Handschke i Monkiewicz, 2010: 87): ubezpieczenia komunikacyjne, dla gospodarstw domowych, dla podróżnych, ubezpieczenia morskie, ubezpieczenia lotnicze, ubezpieczenia kolejowe, dla przedsiębiorstw przemysłowych, dla rolników ogólnych ubezpieczeń odpowiedzialności cywilnej oraz ubezpieczenia finansowe. Ubezpieczenia te pozwalają na zabezpieczenie składników majątku na wypadek jego uszkodzenia, zniszczenia czy utraty na skutek zdarzeń losowych (np. pożar, powódź, gradobicie, trzęsienie ziemi). Zatem ubezpieczenia majątkowe dotyczą dóbr w postaci rzeczy lub innych wartości majątkowych. Dobra te są zasadniczo zbywalne, można definitywnie oszacować wartość przedmiotu ubezpieczenia.

Zakres poszczególnych ubezpieczeń mienia regulowany jest $\mathrm{w}$ zawieranej umowie bądź w ustawie. Treść i warunki ubezpieczenia precyzują ogólne warunki umowy (w skrócie - o.w.u). Regulacje te w szczególności dotyczą: zakresu udzielonej ochrony, wyłączenia odpowiedzialności zakładu ubezpieczeń, sposobu oraz systemu szacowania wartości szkód) (Zych, 1981: 97-108). 
W ramach ubezpieczeń majątkowych, ubezpieczeniu podlegają między innymi: mieszkania, domy, domki letniskowe, domy w budowie, magazyny, hale, inne budynki i budowle i ich wyposażenie, maszyny, urządzenia, surowce, towary, wyprodukowane przedmioty, uprawy, produkty rolne, ruchomości domowe (wraz z wyposażeniem znajdującym się wewnątrz), dzieła sztuki, środki płatnicze, papiery wartościowe, biżuterię, jachty, samoloty, statki, łodzie, skutery, rowery a także zwierzęta domowe i hodowlane.

Podstawą do obliczania składki ubezpieczeniowej oraz określenia górnej granicy odpowiedzialności zakładu ubezpieczeń jest suma ubezpieczenia. W ubezpieczeniach majątku rzeczowego obowiązuje zasada wynikająca z Kodeksu Cywilnego, stanowiąca, że suma ubezpieczenia powinna odpowiadać wartości przedmiotu ubezpieczenia (Gniewek i Machnikowski, 2014: 280). Z artykułu 824 k.c. wynika, że kompensacja finansowa uszczerbku na mieniu ma być pełna, ale nie powinna doprowadzić do wzbogacenia się ubezpieczonego, a więc nie powinna być wyższa od wartości szkody (Ustawa z dnia 23 kwietnia 1964 r. - Kodeks Cywilny, art. 824). W świetle nauki prawa cywilnego, pojęcie szkody odnosi się do wszelkich uszczerbków w dobrach lub interesach prawnie chronionych, których poszkodowany doznał w brew swojej woli.

\section{Zachowanie klienta na rynku ubezpieczeń}

Konsumenci decydują się na wykupienie usługi ubezpieczenia, celem przeniesienia ryzyka skutków niewłaściwych decyzji bądź sytuacji losowych na zakład ubezpieczeń (Hyski, 2017: 109-121). Dzieje się to za sprawą psychicznego napięcia, towarzyszącego ludziom w związku z odczuwaniem braku pewności, a także gwarancji ochrony odnoszących się do życia, zdrowia, posiadanego majątku - tzw. potrzeba ubezpieczeniowa. Źródłem tego stanu jest ryzyko, odnoszące się do zdarzenia, które może wystąpić, lecz nie musi. Wystąpienie tego zjawiska może wywołać cierpienie, stratę lub zysk (Ronka-Chmielowiec, 2016: 11). Ze względu na wieloznaczność i złożoność terminu ryzyka, nie ma jednej uniwersalnej definicji tego pojęcia.

Ramą teoretyczną dla badań zachowania konsumentów na rynku ubezpieczeń jest teoria perspektyw autorstwa Kahnemana i Tversky'ego (1979: 263-292). Na podstawie analizy zachowania inwestorów zaobserwowali oni, że na rynku w sytuacjach niepewności, mając do wyboru dwie strategie, ludzie w większości przypadków wybierają wariant inwestycyjny zapewniający im większe prawdopodobieństwo zysku, nawet jeśli alternatywne, bardziej ryzykowne rozwiązanie daje wyższą stopę zwrotu. Zjawisko to opisane zostało przez Kahnema i Tversky'ego za pomocą pojęcia efekt pewności (Czerwonka i Rzeszutek, 2012: 117). Dodatkowo wykazali oni, że jednostki przejawiają niechęć do ryzyka w dziedzinie zysków oraz skłonność do ryzyka w obszarze strat, co zostało określone mianem 
efektu odwrócenia. Decyzje konsumentów na rynku ubezpieczeń związane są raczej z awersją do ryzyka osób je wykupujących, co pozwala uznać je za wypełniające założenia teoretyczne dla efektu pewności.

Bazując na teorii perspektyw, Brighetti i in. (2014: 136-154) wykazali, że to przede wszystkim zmienne emocjonalne i psychologiczne wpływają na podejmowane decyzje ubezpieczeniowe konsumentów. Co więcej, Kunreuther i in. (2013: 15) wykazali, że decyzje te charakteryzują się dużym odstępstwem od w pełni racjonalnych zachowań. Wynika to $\mathrm{z}$ emocji towarzyszących nabywcom, gdyż motywacją do zakupu ubezpieczenia zwykle jest: lęk, żal, awersja do strat (Schwarcz, 2010: 557), przy czym emocje te zależne są od stanu psychicznego nabywcy. Loewensein i inni twierdzą bowiem, że na podejmowanie decyzji wpływ mają stany ,gorące/zimne”. W stanie „,gorącym” decyzje podejmowane są przez afekt, podczas gdy w stanie ,zimnym” poprzez poznanie (Loewenstein, 2000: 426-432).

Jak pisze Devlin (2007: 631-650), znaczna część ubezpieczających wykazuje się lojalnością konsumencką, przejawiającą się w kontynuacji ubezpieczenia w tym samym przedsiębiorstwie. Devlin podkreśla też dużą wagę rekomendacji w procesie decyzyjnym na tym rynku, które okazały się być dużo istotniejszym kryterium wyboru ubezpieczenia niż reputacja marki. Potwierdza to ustalenia Jamesa wskazującego, że ubezpieczający nie zawsze wybierają na rynku najbardziej korzystne oferty z punktu widzenia finansowego. Wicka i Miedzik (2010: 53) podkreślają olbrzymie znaczenie znajomości marki, jako czynnika przesądzającego o wyborze firmy ubezpieczeniowej. Borda i Jędrzychowska (2012: 77) wskazują, że wraz z wydłużeniem się okresu współpracy pomiędzy konsumentem a zakładem ubezpieczeń istotną rolę zaczynają odgrywać takie zmienne jak jakość i wiarygodność świadczonej ochrony. Jak podaje Petra (2012: 20-37), skutecznymi narzędziami służącym zachęceniu konsumenta do wyboru ubezpieczenia konkretnej firmy są też rabaty i zmiana ochrony ubezpieczeniowej. Także i te działania są na tylne silne, aby zakłócić racjonalność decyzji zakupowych. Czuba i Oniszczuk-Jastrząbek (2017: 18) zwracają uwagę na proces dystrybucji produktu ubezpieczeniowego, w którym najważniejszą rolę odgrywa sprzedaż osobista, brak relacji pomiędzy konsumentem a agentem przekłada się na brak dodatkowej wartości dla kupującego, za co ten byłby w stanie zapłacić. Piekut (2018: 69) podkreśla znaczenie rozporządzalnego dochodu w gospodarstwie domowym: wraz $\mathrm{z}$ jego wzrostem rosną także wydatki na ubezpieczenia.

Badania przeprowadzone w krajach europejskich i azjatyckich wykazały ponadto, że dochód (w tym jego dystrybucja), edukacja i urbanizacja są najważniejszymi czynnikami wpływającymi na popyt na ubezpieczenia (Dragos, 2014: 169-180). 


\section{METODYKA}

Celem badania było określenie znaczenia przypisywanego przez konsumentów najważniejszym kryteriom decydującym o wyborze ubezpieczenia. Na podstawie przeglądu literatury przedmiotu z zakresu decyzji zakupowych na rynku ubezpieczeń postawiono następujące hipotezy badawcze ${ }^{1}$ :

- H1: rekomendacje od rodziny i znajomych są ważniejszym czynnikiem wyboru ubezpieczenia niż reputacja marki;

- H2: subiektywnie postrzegana atrakcyjność oferty jest ważniejszym czynnikiem wyboru ubezpieczenia niż postrzegane warunki umowy;

- H3: preferencyjne warunki oferty są ważniejszym czynnikiem wyboru ubezpieczenia niż postrzegane warunki umowy.

Korzystając z metody sondażu diagnostycznego z wykorzystaniem techniki CAWI $(n=150)$, przeprowadzone zostało badanie ankietowe. Ilościowe ujęcie pozwala na wskazanie dominujących społecznie priorytetów w zakresie wyboru oferty ubezpieczeniowej. Próba została wyłoniona w doborze wygodnym, poprzez dystrybucję ankiet w mediach społecznościowych. Kwestionariusz składał się z 28 pytań podzielonych na dwie części. Pierwsza część zawiera pytania odnoszące się do determinant wpływających na wybór ubezpieczenia, zadowolenia z obecnego ubezpieczyciela, powodów, dla których badani się ubezpieczają. Pytania prezentowane były w formie zdań twierdzących, a respondenci proszeni byli o wskazanie na pięciostopniowej skali typu Likerta, w jakim stopniu zgadzają się z kolejnymi twierdzeniami (gdzie 1 - zdecydowanie się nie zgadzam, 5 - zdecydowanie się zgadzam). Druga część to rozbudowana metryczka osobowa.

Klasyfikację najważniejszych czynników przeprowadzono poprzez po przez wyliczenie średniej oraz odchylenia standardowego dla każdej zmiennej (atrakcyjność oferty, cena, warunki umowy, preferencyjna oferta sprzedaży, reputacja ubezpieczyciela, rekomendacje rodziny i znajomych, kontynuacja ubezpieczenia oraz reklama telewizyjna). W etapie drugim, przy pomocy analizy korelacji rang Spearmana wykazano związki pomiędzy poszczególnymi kryteriami. Celem tego działania było ustalenie, które z kryteriów współtowarzyszą innym, a tym samym, jednorodnych grup kryteriów decyzyjnych.

Badanie zostało wykonano w styczniu 2020 roku, wzięło w nim udział 150 osób. Szczegółowy opis próby badawczej prezentuje tabela 2 .

${ }^{1}$ Na podstawie: Brighetti i in., 2014: 136-154; Kahneman i Tversky, 1979: 263-292; Bharadwaj i in., 1993: 83-99; Devlin, 2007: 631-650. 
Tabela 2. Opis próby badawczej

\begin{tabular}{|c|c|}
\hline Płeć & \\
\hline Kobieta & $56,8 \%$ \\
\hline Mężczyzna & $43,2 \%$ \\
\hline \multicolumn{2}{|l|}{ Wiek } \\
\hline$<20$ lat & $1,1 \%$ \\
\hline 20-30 lat & $56,8 \%$ \\
\hline $30-40$ lat & $19,3 \%$ \\
\hline 40-50 lat & $11,4 \%$ \\
\hline$>50$ lat & $11,4 \%$ \\
\hline \multicolumn{2}{|l|}{ Stan cywilny } \\
\hline Kawaler/Panna & $63,6 \%$ \\
\hline Żonaty/Zamężna & $33,0 \%$ \\
\hline Wdowiec/Wdówka & $2,3 \%$ \\
\hline Rozwodnik/Rozwódka & $1,1 \%$ \\
\hline \multicolumn{2}{|l|}{ Wykształcenie } \\
\hline Podstawowe & $2,3 \%$ \\
\hline Średnie & $21,6 \%$ \\
\hline Techniczne & $2,3 \%$ \\
\hline Wyższe & $73,9 \%$ \\
\hline \multicolumn{2}{|l|}{ Aktywność zawodowa } \\
\hline Osoba aktywna zawodowo & $72,7 \%$ \\
\hline Bezrobotny/Bezrobotna & $3,5 \%$ \\
\hline Emeryt/Emerytka & $4,5 \%$ \\
\hline Osoba ucząca się & $19,3 \%$ \\
\hline \multicolumn{2}{|l|}{ Miejsce zamieszkania } \\
\hline Wieś & $36,4 \%$ \\
\hline Miasto do 50 tys. mieszkańców & $18,2 \%$ \\
\hline Miasto do 100 tys. mieszkańców & $12,5 \%$ \\
\hline Miasto do 250 tys. mieszkańców & $6,8 \%$ \\
\hline Miasto powyżej 250 tys. mieszkańców & $26,1 \%$ \\
\hline \multicolumn{2}{|l|}{ Zarobki netto } \\
\hline$<2000 \mathrm{zl}$ & $29,5 \%$ \\
\hline $2000-3000 \mathrm{zt}$ & $36,4 \%$ \\
\hline $3000-5000 \mathrm{zl}$ & $27,3 \%$ \\
\hline$>5000 \mathrm{zl}$ & $6.8 \%$ \\
\hline
\end{tabular}

Źródło: opracowanie własne. 
Spośród badanych 56,8\% stanowiły kobiety, a 43.2\% mężczyźni. Respondenci to głównie osoby młode, w wieku między 20-30 lat (56,8\% badanych), stanu wolnego $(63,6 \%)$. Wśród badanych dominują osoby o wyższym wykształceniu oraz aktywne zawodowo. Średnie zarobki respondentów zawierają się w przedziale pomiędzy 2000 złotych a 3000 złotych netto. Największy odsetek ankietowanych osób jako miejsce swojego zamieszkania wskazuje tereny wiejskie $(36,4 \%)$.

\section{WYNIKI}

Wyniki badania wykazały, że przy wyborze oferty ubezpieczeniowej najważniejszymi kryteriami są: atrakcyjność oferty, cena oraz warunki umowy (tab. 3). Te trzy kryteria z jedne strony charakteryzują się najwyższymi ocenami otrzymanymi przez badanych (powyżej 4.23), z drugiej strony relatywnie niewielką zmiennością nadawanego im znaczenia (odchylenie standardowe poniżej 1).

Tabela 3. Statystyka opisowa badanych zmiennych

\begin{tabular}{|c|c|c|}
\hline Na wybór ubezpieczyciela wpływa atrakcyjność oferty & 4,41 & 0,84 \\
\hline Na wybór ubezpieczyciela wpływa cena & 4,33 & 0,89 \\
\hline Standardowe
\end{tabular}

Źródło: opracowanie własne.

Kryterium, które najbardziej różnicuje respondentów jest deklaracja chęci kontynuacji ubezpieczenia u dotychczasowego ubezpieczyciela. Można więc przyjąć, że konsumenci, których oczekiwania zostają spełnione, nie szukają ofert lepszych finansowo, ale przejawiają elementy zachowań lojalnościowych. 
Najmniejszą rolę odgrywa reklama telewizyjna, co może wskazywać na ograniczone zaufanie badanych do komunikatów płynących z reklam. Przyjmując, że istotnie konsumenci przy wyborze ubezpieczenia kierują się przede wszystkim ceną, komunikację reklamową ubezpieczycieli należy traktować jako narzędzie budowania świadomości marki, nie zaś perswazji klienta (który będzie wybierał najlepszą ofertę ze znanych sobie już firm ubezpieczeniowych).

Kolejnym krokiem analizy była określenia współzależności pomiędzy czynnikami decydującymi o wyborze ubezpieczenia (tab. 4).

Tabela 4. Analiza korelacji rang kryteriów decyzyjnych konsumentów na rynku ubezpieczeń majątkowych

\begin{tabular}{|l|c|c|c|c|c|c|c|c|c|c|}
\hline & 1 & 2 & 3 & 4 & 5 & 6 & 7 & 8 & 9 & 10 \\
\hline 1. Cena & 1,00 & & & & & & & & & \\
\hline 2. Zarobki & 0,07 & 1,00 & & & & & & & & \\
\hline $\begin{array}{l}\text { 3. Najtańsza } \\
\text { wersja }\end{array}$ & 0,14 & $-0,10$ & 1,00 & & & & & & & \\
\hline $\begin{array}{l}4 . \text { Preferen- } \\
\text { cyjna oferta } \\
\text { sprzedaży }\end{array}$ & $0,48^{* *}$ & 0,06 & 0,20 & 1,00 & & & & & & \\
\hline $\begin{array}{l}\text { 5. Warunki } \\
\text { umowy }\end{array}$ & 0,15 & 0,02 & $-0,04$ & $0,33^{* *}$ & 1,00 & & & & & \\
\hline $\begin{array}{l}\text { 6. Kontynua- } \\
\text { cja ubezpie- } \\
\text { czenia }\end{array}$ & 0,06 & $-0,29 *$ & 0,16 & 0,06 & 0,01 & 1,00 & & & & \\
\hline $\begin{array}{l}\text { 7. Reputacja } \\
\text { ubezpieczy- } \\
\text { ciela }\end{array}$ & 0,01 & 0,02 & $-0,06$ & 0,05 & $0,26 *$ & $0,36 * * *$ & 1,00 & & & \\
\hline $\begin{array}{l}\text { 8. Rekomen- } \\
\text { dacje rodziny } \\
\text { i znajomych }\end{array}$ & 0,12 & $-0,01$ & $-0,06$ & 0,00 & $-0,04$ & $0,28^{* *}$ & $0,30 *$ & 1,00 & & \\
\hline $\begin{array}{l}\text { 9. Reklama } \\
\text { telewizyjna }\end{array}$ & $-0,15$ & 0,01 & 0,03 & $-0,08$ & $-0,15$ & 0,15 & $-0,08$ & 0,15 & 1,00 & \\
\hline $\begin{array}{l}\text { 10. Atrakcyj- } \\
\text { ność oferty }\end{array}$ & $0,54 * *$ & 0,06 & 0,04 & $0,45^{* * *}$ & $0,39 * * *$ & 0,04 & 0,20 & 0,08 & $-0,17$ & 1,00 \\
\hline
\end{tabular}

$* * * 0,001 ; * * 0,002 ; * 0,05$

Źródło: opracowanie własne.

Wykazano, że zmiennymi istotnie powiązanymi z ceną ubezpieczenia są: preferencyjna oferta sprzedaży, oraz atrakcyjność ubezpieczenia, czyli kryteria w ramach których również zawiera się czynnik cenowy. Z drugiej strony, zarobki związane są z kontynuacją ubezpieczenia u tego samego ubezpieczyciela. Jak więc widać, osoby lepiej zarabiające po wygaśnięciu polisy nie poszukują 
najlepszych cenowo ofert, ale wiążą się z kolejną umową z dotychczasowym dostawcą usługi ubezpieczeniowej.

Skłonność do pozostania u ubezpieczyciela, z którym wiąże konsumenta umowa większa jest także u osób kierujących się jego reputacją oraz rekomendacjami rodziny i znajomych. Wyraźnie widać więc, że na rynku rysują się dwie grupy kryteriów: cenowe i jej pochodne oraz związane z wizerunkiem i posiadaną bazą konsumentów. Czynnikiem łączącym te dwie grupy są warunki umowy, powiązane niewielką korelacją z reputacją ubezpieczyciela, atrakcyjnością oferty oraz zapoznawaniem się z ogólnymi postanowieniami umowy przed wykupieniem ubezpieczenia.

\section{WNIOSKI}

W badaniu potwierdziła się jedna $\mathrm{z}$ trzech postawionych hipotez badawczych, zakładająca, że subiektywnie postrzegana atrakcyjność oferty jest ważniejszym czynnikiem wyboru ubezpieczenia niż postrzegane warunki umowy. Odrzucono natomiast hipotezy mówiące, że rekomendacje od rodziny i znajomych są ważniejszym czynnikiem wyboru ubezpieczenia niż reputacja marki oraz, że preferencyjne warunki oferty są ważniejszym czynnikiem wyboru ubezpieczenia niż postrzegane warunki umowy. Wyniki badania doprecyzowują przy tym dotychczasowe ustalenia badaczy zajmujących się zachowaniami konsumentów na rynku ubezpieczeń. Na podstawie zidentyfikowanych wcześniej kryteriów decyzyjnych towarzyszących wyborowi ubezpieczenia ustalono, że najważniejszymi z nich są atrakcyjność oferty, cena oraz warunki umowy. Biorąc pod uwagę, że atrakcyjność oferty jest co najmniej umiarkowanie skorelowana $\mathrm{z}$ ceną, należy uznać, że dla badanych kluczową kwestią jest przede wszystkim pozyskanie ubezpieczenia jak najniższym kosztem.

Wyniki tych badań stanowią praktyczną wskazówkę dla podmiotów świadczących usługi ubezpieczeniowe, wskazując im kwestie, które należy uwzględniać przy kreowaniu oraz sprzedaży produktów ubezpieczeniowych konsumentom. Wykazano, że istotną rolę w wyborze ubezpieczenia odgrywają rekomendacje znajomych, co jest z tożsame z wynikami uzyskanymi przez Bharadwaja $\mathrm{i}$ innych [Bharadwaj 1993]. Wskazuje to, że rynek ubezpieczeń również jest przestrzenią, w której marketing szeptany odgrywa istotną rolę w kształtowaniu zachowań konsumenckich. Dowiedziono także, że konsumenci są lojalni względem swoich dotychczasowych ubezpieczycieli, co potwierdziło wcześniejsze odkrycia Devlina. Na tej podstawie można sformułować rekomendację dla ubezpieczycieli, że kluczowym wyzwaniem jest dla nich pozyskanie klienta, biorąc pod uwage relatywnie wysoki stopień deklarowanej retencji konsumentów. 
Badanie posiada pewne ograniczenia. Kluczowym z nich jest dobór próby badawczej, wyłonionej w sposób wygodny, poprzez dystrybucję ankiety kanałami internetowymi. Ponadto, warto w przyszłości poddać weryfikacji odpowiedzi udzielane przez respondentów innymi metodami badawczymi. Jednym z głównych ograniczeń badania jest jego deklaratywny charakter. Na podstawie odpowiedzi udzielonych przez badanych możemy stwierdzić, że klienci nie kierują się reklamami przy wyborze oferty ubezpieczeniowej. Aby wzmocnić zaprezentowane wnioski, wyniki należało by poddać falsyfikacji w badaniu opartym o obserwacje zachowań klientów.

\section{BIBLIOGRAFIA}

Bharadwaj, Sundar G., Varadarajan, P. Rajan i Fahy, J. (1993). Sustainable competitive advantage in service industries: A conceptual model and research propositions. Journal of Marketing, 57.4, pp. 83-99.

Borda, M. i Jędrzychowska, A. (2012). Analiza postaw nabywców ubezpieczeń komunikacyjnych na rynku polskim. Rozprawy Ubezpieczeniowe, 13, ss. 71-81.

Brighetti, G., Lucarelli, C. i Marinelli, N. (2014). Do emotions affect insurance demand, Review of Behavioral Finance, 6(2), ss. 136-154.

Czerwonka, M. i Rzeszutek, M. (2012). Przejawy i uwarunkowania różnic między płciowych w zachowaniach inwestycyjnych z punktu widzenia finansów behawioralnych. Studia $i$ prace kolegium zarządzania i finansów, Zeszyt naukowy SGW w Warszawie, 122, ss. 116-129.

Czuba, T. i Oniszczuk-Jastrząbek, A. (2017). Sposób zakupu ubezpieczeń a kryteria wyboru ubezpieczyciela w segmencie rolny. Ubezpieczenia w Rolnictwie. Materiaty i Studia, 62, ss. 7-20.

Devlin, James F. (2007). Complex services and choice criteria: An example from the life assurance market. Journal of Marketing Management, 23(7-8), pp. 631-650.

Dragos, S.L. (2014). Life and non-life insurance demand: The different effects of influence factors in emerging countries from Europe and Asia. Economic research - Ekonomska istraživanja, 27(1), pp. 169-180.

Gniewek, E. i Machnikowski, P. (2014). Kodeks cywilny. Komentarz, Warszawa: C.H. Beck.

Grenne, M. i Trieschman, J. (1981). Risk and Isourance. Cincinnati: South-Qwestern Publishing Co. Handschke, J. i Monkiewicz, J. (2010). Ubezpieczenia. Warszawa: Poltext.

Hyski, M. (2017). Ubezpieczenie jako instrument finansowej kontroli ryzyka. Prace Naukowe Akademii im. Jana Dlugosza w Czesstochowie. Pragmata tes Oikonomias, 1.11, ss. 109-121.

Kahneman, D. i Tversky, A. (1979). Prospect theory, an analysis of decisions under risk. Economoterica, 47(2), pp. 263-291.

Kunreuther, H.C., Pauly, M.V. i McMorrow, S. (2013). Insurance and Behavioral Economics: Improving Decisions in the Most Misunderstood Industry, Cambridge: Cambridge University Press.

Kwiecień, I. (2016). Charakterystyka produktów z zakresu ubezpieczeń majakowych i pozostałych osobowych. W: W. Ronka-Chmielowiec, red., Ubezpieczenia. Warszawa: C.H. Beck.

Loewenstein, G.F. (2000). Emotions in economic theory and economic behaviour. American Economic Review, 90(2), pp. 426-432.

Petra, M. (2012). Research of the behavior of consumers in the insurance market in the Czech Republic. Journal of Competitiveness, 4(2), pp. 20-37.

Piekut, M. (2018). Zróżnicowanie wydatków na ubezpieczenia w gospodarstwach domowych. Wiadomości Statystyczne, 63(06), ss. 57-72. 
Płonka, M. (2013). Determinanty konkurencyjności towarzystw ubezpieczeń wzajemnych w Polsce. Zeszyty Naukowe Uniwersytetu Ekonomicznego w Krakowie. Seria Specjalna, Monografie, 228, s. 238.

Ronka-Chmielowiec, W. (2016). Ubezpieczenia. Warszawa: C.H. Beck.

Samuelson, P.A. i Nordhaus, W.D. (2012). Ekonomia. Poznań: Dom Wydawniczy REBIS.

Schwarcz, D. (2010). Insurance demand anomalies and regulation. Journal of Consumer Affairs, 44(3), pp. 557-577.

Ustawa z dnia 11 września 2015 r. o działalności ubezpieczeniowej i reasekuracyjnej, Dz.U. 2015, poz. 1844.

Ustawa z dnia 23 kwietnia 1964 r. - Kodeks Cywilny, Dz.U. 1964, nr 16, poz. 93.

Vaugnan, E.J. (1997). Risk Management. New York: John Wiley\&amp; Sons, Inc.

Warkadło, W. (1969). Zasada odszkodowania w ubezpieczeniach. Studia cywilistyczne, XIII-XIV, ss. $417-432$.

Wicka, A. i Miedzik, A. (2010). Rodzaje ubezpieczeń i czynniki decydujące o wyborze ubezpieczyciela. Zeszyty Naukowe Polityki Europejskie, Finanse i Marketing, 4, ss. 264-277.

Zych, J. (1981). Nowe ogólne warunki ubezpieczenia odpowiedzialności cywilnej jednostek gospodarki uspołecznionej. Ruch Prawniczy, Ekonomiczny i Socjologiczny, 43, s. 19.

\section{KRYTERIA DECYZYJNE KONSUMENTA NA RYNKU UBEZPIECZEŃ MAJĄTKOWYCH}

\section{Streszczenie}

Konsumenci chcąc ustrzec się przed stratami wynikającymi z nieprzewidzianych zdarzeń losowych, decydują się na zakup ubezpieczenia. Uznaje się, że podejmowane przez nich decyzje często noszą znamiona irracjonalnych. Celem badania było określenie znaczenia przypisywanego przez konsumentów najważniejszym kryteriom decydującym o wyborze ubezpieczenia. Badanie przeprowadzono metodą sondażu diagnostycznego z wykorzystaniem techniki CAWI w styczniu 2020 roku na grupie 150 osób. Wyniki wykazały, że najważniejszymi czynnikami jakimi przy wyborze ubezpieczenia kierują się konsumenci są: cena, atrakcyjność oferty oraz warunki umowy.

Słowa kluczowe: ubezpieczenia majątkowe, zachowanie konsumenta, ryzyko. 